\title{
Snitches Get Stitches: An Historical Overview of Whistleblower Laws and Perceptions
}

\author{
Paul Fiorelli \\ Xavier University
}

In the U.S., whistleblower protection comes in two forms, anti-retaliation assurance, and bounties. To receive job protection under the Dodd-Frank Act, the U.S. Supreme Court held that employees must report to the SEC, or they will not satisfy the definition of a whistleblower. Since the time of the Civil War, with profiteers abusing their government contracts, the False Claims Act has rewarded employees reporting on organizations stealing from the government. While the U.K. and France protect whistleblowers, who are targeted by their employers, no other government provides a bounty.

Keywords: whistleblower, false claims, act, Qui Tam, sarbanes-oxley, Dodd-Frank, U.K. Bribery Act, Sapin II, EU whistleblowing directive, retaliation, inaction.

\section{STATUTORY PROTECTIONS FOR WHISTLEBLOWERS:}

In a perfect world, whistleblowers would come forward with their concerns, managers would investigate, corrective action would be taken, and the whistleblower would go on with their daily lives, as if nothing had happened. Unfortunately, we do not live in that perfect world. It's more likely that whistleblowers will report potential problems if they believe their concerns will be investigated and jobs protected, or receive some form of financial incentives. This became apparent when profiteers ripped off the government during the Civil War.

\section{Qui Tam Bounties}

Qui tam pro domino rege, quam pro se ipso in hac parte sequitur ("qui tam" for short) is roughly translated into "he [or she] who sues in the name of the king as well as for himself". This concept of private citizens receiving a reward for telling the crown something it did not already know, originated in 695 with a declaration by King Wihtred of Kent. "If a freeman works during the forbidden time [i.e., the Sabbath], he shall forfeit his healsfang (sum a person would pay to avoid the pillory), and the man who informs against him shall have half the fine, and [the profits arising] from the labour" (Doyle, 2009). King Wihtred apparently knew that one way of getting people to inform on their neighbors who were breaking the laws, was to offer them a percentage of the fines assessed, plus a share of their ill-gotten gains. This concept continued throughout the centuries in England and was transplanted to America during the Civil War.

"A jobber from Vermont, Jim Fisk, twisted his swagger mustache and grinned with a cock of his eye, 'You can sell anything to the government at almost any price you've got the guts to ask" (Sandburg, 1954, p. 278). This was the mentality of many government contractors, even those without swagger 
mustaches. The Brooks Brothers logo of a lamb suspended in a ribbon was adopted in 1850, "when it was painted above our shop door in New York, this nod to British tradition has symbolized heritage, quality and legendary service ever since." Unfortunately for union soldiers, this quality seemed absent from their contract with the northern army.

But this was not the worst of it: facing a paucity of wool, Brooks Brothers glued together shredded, often decaying rags, pressed them into a semblance of cloth, and sewed the pieces into uniforms. Far from protecting the soldiers from inclement weather, these uniforms would fall apart in the first rain. The New York State Legislature eventually spent $\$ 45,000$ - about $\$ 10.8$ million in current dollars - to replace the uniforms. (Sandburg, 1954, p. 278).

With clothes made from this "shoddy material", union soldiers risked fighting in the rain, in nothing more than their union suits. The word "shoddy" has morphed from a noun meaning cheap fabric from waste cloth, into an adjective covering all situations - "badly made or done".

During the Civil War, there was no FBI to probe, or Department of Justice to prosecute these claims. It was not until 1870 that the Attorney General of the United States was even a full-time position. President Lincoln recognized this problem, and like King Withred, decided to incentivize people to become private attorneys general, suing profiteers on behalf of the government.

Two months after President Lincoln issued the Emancipation Proclamation, the False Claims Act was enacted. This "Lincoln Law" even allowed conspirators to turn on their previous associates, in order to collect a bounty. Senator Howard was a sponsor of the bill and spoke of its tactics.

In short, sir, I have based the fourth, fifth, sixth, and seventh sections upon the oldfashion idea of hold out a temptation, and 'setting a rogue to catch a rogue,' which is the safest and most expeditious way I have ever discovered of bringing rogues to justice (Doyle, 2009).

This idea of using a bad guy to catch a bad guy could have been the inspiration for the Department of Justice, Antitrust Division's Corporate Leniency policy regarding price fixing. The first offender to break ranks and inform the DoJ about the price fixing scheme, gets a pass from criminal prosecution and fines (Hammond, 2008). It seems government incentives can come in the form of money, freedom or both.

The False Claims Act was revised in 1986 and has been a successful source of income for the US government, and qui tam relators alike. In its first four years (1987-1991), the government only collected $\$ 128,468,802$ based on these lawsuits, but that has steadily risen and the most recent four-year statistics (2015-2018) show the government recouping \$10,742,418,011 (Civil Division, U.S. Department of Justice, 2018).

\section{Sarbanes-Oxley Act of 2002}

The Time Magazine "People of the Year" in 2002, were three female whistleblowers - Colleen Rowley (FBI), Cynthia Cooper (Worldcom) and Sherron Watkins (Enron). While these three gained some celebrity status, their financial situations were bleaker. Each was fired, and Congress realized the need to provide some form of protection for whistleblowers, to encourage them to alert the government about potential failures, as soon as possible. Legislators quickly passed sweeping legislation in the form of Sarbanes-Oxley (SOX), which included whistleblower anti-retaliation section $\S 806$, prohibiting publicly traded companies from firing, demoting or threatening an employee who reasonably believed a securities fraud had occurred.

Sarbanes-Oxley has a broad definition of an Employee, who may receive whistleblower protection. 'Employees' means an individual presently or formerly working for a covered person, an individual applying to work for a covered person, or an individual whose employment could be affected by a covered person (Occupational Health and Safety Regulation, n.d.). This employee would be protected 
under Sarbanes-Oxley against retaliation for providing information to a regulator or law enforcement agency, a member of Congress, or one of the employee's supervisors. There is no obligation for employees to report to the SEC, in order to receive Sarbanes-Oxley anti-retaliation protection. That will not be the case for job security under Dodd-Frank.

\section{Dodd-Frank Act of 2008}

This law was passed to give additional incentives to insiders who could help prevent future financial failures. While $\S 806$ of Sarbanes-Oxley promised anti-retaliation protections, $\S 922$ of Dodd-Frank would provide "bounties", similar to the False Claims Act. If the SEC fined the violator over $\$ 1,000,000$, rewards could be between $10-30 \%$ of the amount collected.

One of the major questions that arose from $\$ 922$ was whether a whistleblower had to report internally first, in order to qualify for the reward. Ethics and Compliance Officers, along with Internal Auditors and General Counsels argued that they spent significant resources developing the reporting mechanisms required by SOX, and now Dodd-Frank. They feared that whistleblowers would race to the courthouse, or in this case the SEC, in order to preserve their bounty. Employers believed they should at least get "first dibs" on the information, before it went to the government. Whistleblowers and their attorneys argued that they should be able to circumvent the company's reporting mechanisms, and go straight to the SEC. Some feared that if they reported internally first, they would be immediately fired and escorted from the building by security. Their documentation might be detected, deleted and destroyed, before ever seeing the light of day. On May 25, 2011 the SEC reached a compromise position in a 3-2 vote (Securities Whistleblower Incentives and Protections, 2011). Given the 10-30\% discretionary reward range, the SEC has some leeway. It would encourage, but not require whistleblowers to report internally first, by offering bounties on the higher range of the $10-30 \%$ scale.

\section{SEC Office of the Whistleblower}

After Dodd-Frank was passed, the SEC established the "Office of the Whistleblower" in order to encourage more reporters to come forward. Potential whistleblowers deal with the SEC by filing a form for Tips, Complaints or Referral (TCR) (U. S. Securities and Exchange Commission, Form TCR, n.d.). As of 2019, "[T] he SEC has now awarded approximately $\$ 376$ million to 61 individuals since issuing its first award in 2012. All payments are made out of an investor protection fund established by Congress that is financed entirely through monetary sanctions paid to the SEC by securities law violators" (U. S. Securities and Exchange Commission, 2019, March 26). The highest individual award, to date, was a $\$ 50$ million award in March of 2018. (U. S. Securities and Exchange Commission, 2019, March 19).

These awards demonstrate that whistleblowers can provide the SEC with incredibly significant information that enables us to pursue and remedy serious violations that might otherwise go unnoticed," said Jane Norberg, Chief of the SEC's Office of the Whistleblower. "We hope that these awards encourage others with specific, high-quality information regarding securities laws violations to step forward and report it to the SEC." (U. S. Securities and Exchange Commission, 2019, March 19).

US employees were now "money players" who could use the False Claims Act or Dodd-Frank to pay for their knowledge about illegal activity.

\section{Digital Realty Trust v. Somers}

Dodd-Frank had two separate whistleblower protection provisions - one dealing with reward, and another with anti-retaliation. While the SEC could incent, but not require whistleblowers to report internally first, would whistleblowers who only reported internally receive anti-retaliation protection? This was the fact situation the Supreme Court addressed in Digital Trust v. Somers. Mr. Somers conveyed his concerns to his company, but not the SEC. He was fired and brought an anti-retaliation lawsuit against his former employer. In a 9-0 decision written by Justice Ginsberg, the court held: 
In sum, Dodd-Frank's text and purpose leave no doubt that the term "whistleblower" in $\S 78 \mathrm{u}-6(\mathrm{~h})$ carries the meaning set forth in the section's definitional provision. The disposition of this case is therefore evident: Somers did not provide information "to the Commission" before his termination, $\S 78 \mathrm{u}-6(\mathrm{a})(6)$, so he did not qualify as a "whistleblower" at the time of the alleged retaliation. He is therefore ineligible to seek relief under $\S 78 \mathrm{u}-6(\mathrm{~h})$ (Digital Realty v. Somers, 2018).

While the Supreme Court unanimously agreed with Digital Trust, the message may discourage internal reporting. In order to be covered by the anti-retaliation provisions of Dodd-Frank, whistleblowers now must report to the SEC. The only remaining question is whether they should report internally first, with the hope of securing a higher payout in the 10-30\% bounty scheme? This is the balancing test that all future US whistleblowers will wrestle with, post-Digital RealtyTrust.

\section{EUROPEAN PERSPECTIVES}

Growing up in the US, anyone who told on their childhood friends were considered "rats", "snitches", or "tattlers". This mindset continued into the adult workplace, and whistleblowers risk isolation or even termination for "doing the right thing". Disdain for whistleblowers is even stronger and more engrained in Europeans, especially anonymous reporting in France and Germany, due to tragic events during WWII:

It has been argued that the attitude of the French and German authorities in these cases is influenced by a deep cultural unease about the concept of whistleblowing itself. Both countries have experienced in their history how the ability of individual citizens to provide information to those in authority, allegedly for the purpose of protecting a higher common good, has been abused by those individuals for their own selfish motives. Germany, in particular, still suffers from its dual experience of mass denunciations during the Hitler regime and in the former GDR. The latter regime, in the form of its Ministry for State Security, heavily relied on the information provided by a network of so called "Inofficial Contributors" for the establishment of a system of almost total surveillance and control of its populace. A feeling therefore seems to dominate which likens the act of "blowing the whistle" to that of denunciation, with the latter being tarnished with considerable social and historical stigma (Rauhofer, 2007).

Without adequate protection against retaliation, it is easy to understand why Europeans might be unwilling to "blow the whistle" on wrongful acts.

\section{United Kingdom - PIDA and the UK Bribery Act}

In 1998, the Public Interest Disclosure Act (PIDA) amended the Employment Rights Act of 1996 and established a framework for protecting all UK employees against reprisal for making a "protected disclosure" (United Kingdom, Whistleblower Protection, n.d.). The following actions qualify for protection:

- that a criminal offence has been committed, is being committed or is likely to be committed,

- that a person has failed, is failing or is likely to fail to comply with any legal obligation to which he is subject,

- that a miscarriage of justice has occurred, is occurring or is likely to occur,

- that the health or safety of any individual has been, is being or is likely to be endangered,

- that the environment has been, is being or is likely to be damaged, or

- that information tending to show any matter falling within any one of the preceding paragraphs has been, is being or is likely to be deliberately concealed. (United Kingdom, Whistleblower Protection, n.d.). 
The PIDA allows for a three-pronged approach to disclosure. Workers are allowed to internally report to their employers, to a regulator, or under extreme circumstances - the press. If they can prove they were fired as a result of the whistleblowing, the PIDA allows them to claim unfair dismissal. These workers can ask an employment tribunal for reinstatement or damages, not subject to a statutory cap (Employment Tribunals, 2013). "For example, in July 2005, a prison officer was awarded record damages of GB $£ 477,600$ (about US\$872,203) for unfair constructive dismissal as a result of making a disclosure about abuse and bullying in the prison (Lingard v HM Prison Service 1802862104, 30 June 2005)" (Collins \& Culver, n.d.).

The British government realized the crippling impact bribery has on business and people and passed The UK Bribery Act of 2010:

Bribery blights lives. Its immediate victims include firms that lose out unfairly. The wider victims are government and society, undermined by a weakened rule of law and damaged social and economic development. At stake is the principle of free and fair competition, which stands diminished by each bribe offered or accepted. (The Bribery Act 2010: Guidance, 2011).

This law created a new offence dealing with commercial enterprises that failed to prevent bribery. Individuals and companies faced substantial penalties unless they used "adequate procedures" to deter the bribes. While the legislation itself does not mention whistleblowing, the guidance published by the Ministry of Justice does consider "speak up" or "whistleblowing" procedures as an indicator of a bribery prevention procedure (The Bribery Act 2010: Guidance, 2011).

David Green, the Director of the Serious Fraud Office (SFO) in the UK recognized the impact whistleblowers make in discovering wrongdoing, but he did not agree that whistleblowers needed financial rewards to come forward:

... increasingly, corporate employees are coming to the SFO and blowing the whistle. "It empowers the individual," he said. That's the case even if the SFO doesn't have a program to compensate whistleblowers financially. Asked whether he believes if the SFO would get more whistleblowers if a financial reward was offered, Mr. Green said: "Quite possibly, but I don't know. There's something quite un-British about it...people recognize there's a sort of a civic duty" to report wrongdoing. (Stein, 2016).

Apparently, Mr. Green does not see eye to eye with King Wihtred about what is and is not "British".

\section{France and Sapin II}

In the early 2000's American companies had difficulty implementing one world-wide hotline program, which could permit anonymous reporting, especially in France. In 2005, the French Data Protection Authority - Commission Nationale de l'Informatique et des Libertés - (CNIL) - adopted an accommodation, allowing companies:

All whistleblowing schemes must be registered with the CNIL, either by filing for a specific request for authorization or, where strict criteria could be met, by making a declaration that the scheme falls within the so-called "Single Authorization" rules. However, prior to the CNIL's recent decision, the Single Authorization rules were not terribly flexible and indeed limited whistleblowing schemes to a finite set of subjects that could be reported: finance; accounting; banking and anticorruption issues; anticompetitive practices; workplace discrimination and harassment; workplace health, hygiene and safety issues; and environmental issues. All other whistleblowing subjects not falling within the Single Authorization would have to be approved specially by the 
CNIL, but would meet with invariable bureaucratic intransigence. (Bryan Cave Leighton Paisner, 2017).

French whistleblowers have newfound hope and protection after the December 9, 2016 passage of Law No. 2016-1691, known as "Sapin II":

While whistleblowing mechanisms already existed in certain areas, the Sapin II Law has created a common set of rights to all whistleblowers. These rights, the non-application of which is criminally punished, include inter alia:

- the guarantee to preserve the whistleblower's anonymity;

- the prohibition to dismiss, penalize, or discriminate against the whistleblower who has observed the whistleblowing procedure; and

- the whistleblower's lack of criminal liability provided that the definition criteria laid out by the Sapin II Law are fulfilled, that disclosure of the information "is necessary and proportionate to safeguard the interests at stake" and that it is made in compliance with the whistleblowing procedures.

However, the Sapin II Law does not provide for an incentive system for whistleblowers like those in place in the United States, where the whistleblower can receive a portion of the fines imposed on the company that breached its obligations. (Bailly \& Haranger, 2017)

The punishment for preventing someone from reporting their concerns under Sapin II are up to one year in prison and a fine of EUR 15,000 for an individual, and up to EUR 75,000 for a legal entity (Malgrain, Jaurett, Menard \& Salha, 2017). Under Sapin II, employees reporting wrongdoings should be able to overcome the stigma previously associated with whistleblowers.

\section{EU Whistleblowing Directive}

On April 16, 2019, the European Parliament adopted a directive to encourage more uniform whistleblower protection.

Persons who work for a public or private organisation or are in contact with it in the context of their work-related activities are often the first to know about threats or harm to the public interest which arise in this context. By 'blowing the whistle' they play a key role in exposing and preventing breaches of the law that are harmful to the public interest and in safeguarding the welfare of society. However, potential whistleblowers are often discouraged from reporting their concerns or suspicions for fear of retaliation. In this context, the importance of providing balanced and effective whistleblower protection is increasingly acknowledged both at European and international level. (Svoboda \& Rozier, 2019).

Countries in the EU have two years after passage to develop standards that comply with the minimum protections of whistleblowers.

\section{CONCLUSION}

Whistleblowers are caught between conflicting concepts concerning corporate fidelity. Do they violate their duty of loyalty as an employee of the company by coming forward with potentially damaging information (the rock), or breach their duty as a citizen to protect the public good (the hard place)? Is the whistleblower the hero, or the villain? The goat, or the G.O.A.T. (Greatest of All Time)? Will they cost their friends jobs by reporting their involvement in possible problems, or save them and the company from making life altering mistakes? These and other questions are swirling around the whistleblower's brains, trying to come up with the best decision. 
Two of the biggest reason's whistleblowers do not report are retaliation and inaction (Ethics and Compliance Initiative, 2012). There is a saying in Japan - "The Nail that Sticks Out Gets Hammered". In general, we avoid confrontation. We like to be liked. Go with the flow. We do not like to stick out, and don't want to get hammered down. Retaliation is not as simple as being fired as soon as the whistleblower files a complaint. It's often more subtle. Indirect. "Once high-performing, well-respected employees blow the whistle, suddenly they become, in retrospect, terrible, if not incompetent employees" (Oreskovic, 2004). The whistleblower may have received excellent evaluations in the past, but now is being placed on a performance improvement plan (PIP) and risks losing their expected bonuses and promotions. Their entire team may have gone out for drinks every Friday after work, and now the team still goes, they just don't invite the whistleblower anymore.

Abraham Lincoln recognized how important it was to encourage his cabinet to tell him about potential problems, without worrying about their jobs. Presidential biographer Doris Kearns Goodwin reported Lincoln's position on this issue - "Good leadership requires you to surround yourself with people of diverse perspectives who can disagree with you without fear of retaliation" (Goodwin, n.d.). Lincoln understood that having an administration of people who were afraid to disagree with, or even contradict him, would lead to a poor decision-making environment. Employees who are not comfortable that they can report problems internally first, without fear of retaliation, will either learn to ignore the potential problems, leave, or take the information outside the company.

Churchill said, "I never worry about action but only inaction" (Langworth, 2009). This is the second fear whistleblowers have - managerial inertia. Why should the whistleblower bother? Why risk their job, career, livelihood, family, if the company is going to ignore their concerns? Employees don't want platitudes, pens and posters promoting values. They want results!

The solution to both of these issues is for the company's leadership to create a trusting environment in which people feel comfortable coming forward with any concerns about how the company is being run. They should know that they won't be placing their jobs in jeopardy if they make a report, and they need to know that any report they make will be investigated. In fact, you could argue that management has failed if an employee makes a whistleblower report to the Securities and Exchange Commission or other agency outside the company. Company leaders must create an environment in which associates feels completely comfortable reporting the problem internally. Whistleblowers typically do not come forward because they want fame or fortune. They just want to help the company correct a potential or actual problem.

\section{REFERENCES}

Bailly, A., \& Haranger, X. (2017, November 27). Sapin II Law: The New French Anticorruption System. Retrieved from https://www.morganlewis.com/pubs/sapin-ii-law-the-new-french-anticorruptionsystem

Bryan Cave Leighton Paisner. (2017, August 10). CNIL Decision on Whistleblower Hotlines. Retrieved from https://www.bclplaw.com/en-US/thought-leadership/cnil-decision-on-whistleblowerhotlines.html

Civil Division, U.S. Department of Justice. (2018, September 30). Fraud Statistics - Overview, October 1, 1986-September 30, 2018. Retrieved from https://www.justice.gov/civil/page/file/1080696/download

Collins, E., Culver, M., \& Hastings, P. (2006, May 1). Rights and Protections for Whistleblowers. Retrieved from https://uk.practicallaw.thomsonreuters.com/2-203 2258 ?transitionType $=$ Default $\&$ contextData $=($ sc. Default $) \&$ firstPage $=$ true $\&$ comp $=$ pluk $\& b h c p=1$

Digital Realty Trust v. Somers, 138 S.Ct.767 (2018).

Doyle, C. (2009, August 6). Qui Tam: The False Claims Act and Related Federal Statutes (CRS Report No. 40785). Retrieved September 2, 2016 from Congressional Research Service Website: https://fas.org/sgp/crs/misc/R40785.pdf 
Employment Tribunals - valuing a claim - where to start. (n.d.). Retrieved June 13, 2019 from https://www.citizensadvice.org.uk/work/problems-at-work/employment-tribunals-from-29-july2013/employment-tribunals-valuing-a-claim/employment-tribunals-valuing-a-claim-where-tostart/

Ethics and Compliance Initiative. (2012). Inside the Mind of a Whistleblower: A Supplemental Report of the 2011 National Business Ethics Survey.

Goodwin, D. K. (n.d.). Retrieved from https://pittsburghlectures.org/lectures/doris-kearns-goodwin/

Hammond, S. D., \& Barnett, B. A. (2017, January 26). Frequently Asked Questions Regarding the Antitrust Division's Leniency Program and Model Leniency Letters. Retrieved from https://www.justice.gov/atr/frequently-asked-questions-regarding-antitrust-divisions-leniencyprogram

Langworth, R. (2008). Churchill By Himself: The Definitive Collection of Quotations. New York: Public Affairs.

Malgrain, L., Jaurett, A., Menard, V., \& Salha, J. (2017, May 30). Duty to Set Up Procedures Enabling Whistleblowing in France by $1^{\text {st }}$ January 2018: Criminal/Labor Consequences. https://www.whitecase.com/publications/alert/duty-set-procedures-enabling-whistleblowingfrance-1st-january-2018-criminal.

Occupational Health and Safety Regulation, Procedures for the Handling of Discrimination Complaints Under Section 806 Of the Corporate and Criminal Fraud Accountability Act of 2002, Title VIII of the Sarbanes-Oxley Act of 2002. 29 C.F.R. $§ 1980.101(\mathrm{~g})$.

Oreskovic, A. (2004, June 4). Can You Hear Those Whistles Blowing? The Recorder.

Rauhofer, J. (2007). Blowing the Whistle on Sarbanes-Oxley: Anonymous Hotlines and the historical Stigma of Denunciation in Modern Germany. International Review of Law, Computers and Technology, 21, 363-376. Retrieved from https://doi.org/10.1080/13600860701714507

Sandburg, C. (1954). Abraham Lincoln: The Prairie Years and the War Years. San Diego, New York, London: Harvest Book, Harcourt.

Stein, M. L. (2016, November 10). SFO Says UK Lawyers Still Grappling with DPAs. Wall Street Journal. https://blogs.wsj.com/riskandcompliance/2016/11/10/sfo-says-uk-lawyers-stillgrappling-with-dpas/.

Svoboda, P., \& Roziere, V. (2019). Amendment 155, Amendments by the European Parliament to the Commission Proposal Directive (EU) 2019... of the European Parliament and of the Council of ... on the protection of persons reporting on breaches of Union law. Retrieved June 11, 2019 from http://www.europarl.europa.eu/doceo/document/A-8-2018-0398-AM-155-155_EN.pdf.

The Bribery Act 2010: Guidance. (2011) Retrieved June 13, 2019 from https://www.justice.gov.uk/downloads/legislation/bribery-act-2010-guidance.pdf.

United Kingdom - Whistleblower Protection. (n.d.) Blueprint for Free Speech, Retrieved June 13, 2019 from https://blueprintforfreespeech.net/document/united-kingdom/\#footnote14.

United States Securities and Exchange Commission Documents and Publications. (2011, June 13). Securities Whistleblower Incentive and Protections. Retrieved from https://www.govinfo.gov/content/pkg/FR-2011-06-13/pdf/2011-13382.pdf.

United States Securities and Exchange Commission. (2019, March 26). SEC Awards \$50 Million to Two Whistleblowers. Retrieved from https://www.sec.gov/news/press-release/2019-42.

United States Securities and Exchange Commission. (2018, March 19). SEC Announces Its Largest-Ever Whistleblower Awards. Retrieved from https://www.sec.gov/news/press-release/2018-44.

United States Securities and Exchange Commission, Form TCR, Tip, Complaint or Referral. Retrieved June 13, 2019 from http://www.sec.gov/about/forms/formtcr.pdf. 